\title{
Lung transplantation: a comprehensive journey
}

A young previously healthy female developed COVID-19 related lung failure requiring intubation, mechanical ventilation, sedation, and proning. She progressed with single organ failure to the point that she could not be oxygenated. We placed her on venovenous extracorporeal membrane oxygenation (ECMO). As typical for many of these patients she had a long ECMO run for more than 90 days. During her ECMO run, she was never a candidate for lung transplantation due to lack of strength and conditioning. She was eventually decannulated from ECMO and began to weaning from the ventilatory with ventilatory management through tracheostomy which was placed early in her course. She is still not progressing with the physical capacity to get through a transplant and her lung function is consistent with a fibrosis that will not improve. Her only hope will be for new lungs. She is caught between the proverbial "Scylla and Charybdis". How many of us have such patients in our intensive care units during the COVID-19 pandemic?

Lung transplantation is the most viable option for many pulmonary diseases in appropriate candidates when medical therapy has failed. This series of manuscripts in this issue was planned prior to the pandemic. Donors remain rate-limiting and the field has been rapidly evolving with innovative approaches resulting in improved outcomes for recipients receiving grafts. Since the planning of this issue we have been burdened with the COVID-19 pandemic and lung failure has become first and foremost in our lives. When one contemplates to potential magnitude of lung failure upon us, it is quite concerning. At the time this was written, over 220 million people worldwide and 40 million in the United States alone have been afflicted with COVID-19. Approximately $10-15 \%$ of these patients will have severe illness. The number of lung transplants for patients with COVID-related lung failure is increasing since the first one being performed in 2020. The number of patients we will be burdened with related to fibrotic disease is uncertain, but what is certain is the merit of concern when one contemplates these potential numbers.

We are grateful to the colleagues from around the world that have contributed to the body of work. They are experts in the field of lung transplantation who have updated their work recently to make this series current with relationship to the pandemic and all we have learned regarding lung failure. The scope of the issue is intentionally broad and is meant to encompass all major relevant topics in lung transplantation. My aim is to make it current, thought-provoking, and stimulating. We also hope it serves as a reference tool for key aspects and areas of controversy in our specialty. I also would like to thank the Fournal of Thoracic Disease for all of their hard work and support with this project. I sincerely hope that you all use these expert reviews to their fullest and they generate the enthusiasm I have had, at least in part, in putting this series together.

\section{Acknowledgments}

Funding: None.

\section{Footnote}

Provenance and Peer Review: This article was commissioned by the editorial office, Fournal of Thoracic Disease for the series "Lung Transplantation: Past, Present, and Future". The article has undergone external peer review.

Conflicts of Interest: The author has completed the ICMJE uniform disclosure form (available at https://dx.doi.org/10.21037/jtd21-1592). The series "Lung Transplantation: Past, Present, and Future" was commissioned by the editorial office without any funding or sponsorship. JD served as the unpaid Guest Editor of the series and serves as an unpaid editorial board member of Fournal of Thoracic Disease from February 2021 to January 2023. The author has no other conflicts of interest to declare.

Ethical Statement: The author is accountable for all aspects of the work in ensuring that questions related to the accuracy or integrity of any part of the work are appropriately investigated and resolved.

Open Access Statement: This is an Open Access article distributed in accordance with the Creative Commons Attribution- 
NonCommercial-NoDerivs 4.0 International License (CC BY-NC-ND 4.0), which permits the non-commercial replication and distribution of the article with the strict proviso that no changes or edits are made and the original work is properly cited (including links to both the formal publication through the relevant DOI and the license). See: https://creativecommons.org/licenses/by-nc$\mathrm{nd} / 4.0 /$.

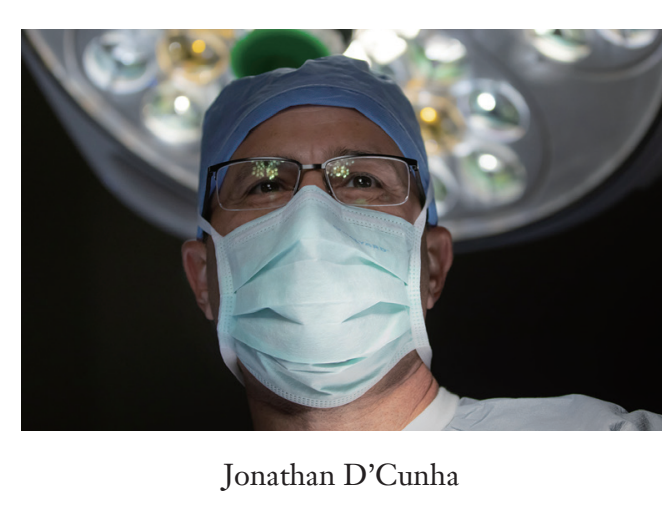

Jonathan D'Cunha Department of Cardiothoracic Surgery, Mayo Clinic Arizona, Phoenix, AZ, USA. (Email:DCunha.7onatban@mayo.edu) Submitted Oct 04, 2021. Accepted for publication Oct 18, 2021. doi: $10.21037 /$ jtd-21-1592 View this article at: https://dx.doi.org/10.21037/jtd-21-1592

Cite this article as: D'Cunha J. Lung transplantation: a comprehensive journey. J Thorac Dis 2021;13(11):6502-6503. doi: $10.21037 /$ jtd-21-1592 